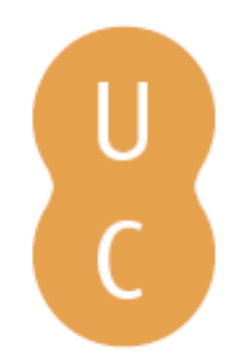

\title{
pombalina
}

\section{Understanding the dynamics of inclined and wind-driven flames in wildland fires}

Autor(es): $\quad$ Gollner, M. J.; Tang, W.; Miller, C. H.; McAllister, S.; Finney, M. A.

Publicado por: Imprensa da Universidade de Coimbra

URL

persistente: URI:http://hdl.handle.net/10316.2/44593

DOI: $\quad$ DOI:https://doi.org/10.14195/978-989-26-16-506_76

Accessed : $\quad$ 26-Apr-2023 03:43:00

A navegação consulta e descarregamento dos títulos inseridos nas Bibliotecas Digitais UC Digitalis, UC Pombalina e UC Impactum, pressupõem a aceitação plena e sem reservas dos Termos e Condições de Uso destas Bibliotecas Digitais, disponíveis em https://digitalis.uc.pt/pt-pt/termos.

Conforme exposto nos referidos Termos e Condições de Uso, o descarregamento de títulos de acesso restrito requer uma licença válida de autorização devendo o utilizador aceder ao(s) documento(s) a partir de um endereço de IP da instituição detentora da supramencionada licença.

Ao utilizador é apenas permitido o descarregamento para uso pessoal, pelo que o emprego do(s) título(s) descarregado(s) para outro fim, designadamente comercial, carece de autorização do respetivo autor ou editor da obra.

Na medida em que todas as obras da UC Digitalis se encontram protegidas pelo Código do Direito de Autor e Direitos Conexos e demais legislação aplicável, toda a cópia, parcial ou total, deste documento, nos casos em que é legalmente admitida, deverá conter ou fazer-se acompanhar por este aviso. 


\section{ADVANCES IN}

\section{FOREST FIRE RESEARCH}

\section{8}

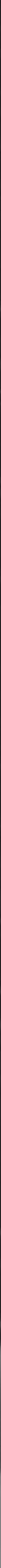




\title{
Understanding the dynamics of inclined and wind-driven flames in wildland fires
}

\author{
M.J. Gollner ${ }^{1 *}$; W. Tang ${ }^{1}$; C.H. Miller ${ }^{1}$; S. McAllister²; M.A. Finney ${ }^{2}$ \\ ${ }^{1}$ University of Maryland, College Park, Department of Fire Protection Engineering. 3106 J.M. \\ Patterson Bldg., College Park, Maryland 20742, United States, \{mgollner@umd.edu*\} \\ ${ }^{2}$ US Forest Service, Missoula Fire Sciences Lab, Missoula, MT 59808, USA
}

\begin{abstract}
Time-dependent movements described as pulsing, puffing or swaying are among the most visible characteristics of open flames. Most existing models for wildfires, however, have assumed flames are motionless and spread at a constant rate via radiation, neglecting any clearly intermittent behaviour. Recent studies of spreading wildfires suggest that flame spread in fine fuel beds is driven by non-steady convective heating and intermittent flame contact on fuel particles. To further understand the impact and nature of these flame motions, a stationary, non-spreading fire configuration has been used as it allows for a thorough statistical analysis of the flame structure. The same intermittent heating observed in the fuel bed experiments were observed in the stationary burner, but with the ability to collect a larger data set. Scaling analyses which investigate the impact of these structures, theories on their generation and their impact to fire spread will be discussed for both wind-driven and slope-dominated flames.
\end{abstract}

Keywords: wildland fire, wind-driven, flames

\section{Overview}

Recent research (Finney et al. 2015) has emphasized the importance of convective heating in wildfire spread across fine fuel elements, indicating that an understanding of the dynamics of an intermittent flame will aid a description of the flame spread process. Although radiation was often ascribed as the dominant mechanism of flame spread in large scale fires, experimental data has shown that the fine elements present in wildland fuel beds will not ignite until they come into contact with flames due to convective cooling (Martin 1965; Rothermel and Anderson 1966; Fang and Steward 1969; Alvares et al. 1970; Baines 1990). An account of the flame dynamics responsible for this process is essential in order to develop a fundamental theory of fire spread in wildland fuels. The important mechanisms associated with flame spread in the turbulent regime of a wildland fire are very difficult to study in the field; for this reason, laboratory experiments can be employed to mimic some aspects of what is seen in the field.

Wildland fire spread is typically described as a function of fuel, weather, and topography. Therefore, an understanding of how these parameters affect the flame dynamics can help to close the gap on our understanding of the flame spread process. In particular, wind and slope are key contributors to flame spread. Steep slopes and high winds are often associated with extreme wildland behavior where flames spread faster and more erratically. As a fire spreads up a slope, the natural buoyancy of the hot gases allows flames to extend over a larger portion of unburnt fuel, accelerating the flame front in the upslope direction. Wind similarly tilts the flame forward which causes increased rates of heating and flame spread.

Although empirical models of the influence of slope and wind have been developed (Rothermel 1972), flame dynamics is still an active area of study. If fine fuels are affected by intermittent heating processes, time-dependent movements of the flame will affect heating that drives flame spread. The flames three-dimensional structure is also important to understanding this behavior, however this has yet to be fully characterized. 
This work will first review a number of studies by the authors aimed at characterizing flame structures associated with wind-driven and inclined flame spread using stationary burners. Using stationary fires, the fire's movement and behavior with respect to the wind and slope can be investigated in a consistent manner, separated from fuel ignition effects. Measurements of the flame structure and its effects in space and time are made using image analysis and heat-flux and temperature profiles of the flame under both wind and slope. While the flames used in these laboratory experiments are smaller and less turbulent than those found in a real wildland fire, their structure still retains similar features, in particular the interaction between momentum and buoyancy which governs liftoff of the flame (Quintiere 1989). Because these features are critically important to fire spread, careful study at this small scale may still help inform larger-scale work performed in the future. Results are also presented for new work focused on time-dependent movements of the flame. Previous work from the authors did not correlate these downstream frequencies which are important for intermittent heating of fine fuels, however a new relationship is presented here which provides more insight into the controlling processes of these forward movements.

\section{Review of Previous Work}

Fire science has long used stationary fires to help understand forward heating effects in concurrent flame spread (de Ris et al. 1975; Ahmad and Faeth 1979; Quintiere et al. 1986). A review of previous work on flow and geometry effects on concurrent flame spread was recently given in (Gollner et al. 2017). The focus of the review here will be on work by the authors related to stationary burners and wildland fires.

Gorham et al. studied the behavior of stationary fires using both gas burners and liquid fuel-soaked wicks under forced flows and inclined geometries (Gorham et al. 2014). A mechanism of instability was found in these flows, namely the formation of streamwise streaks, later forming spanwise "peaks and troughs" which were found to be similar to other fluid dynamic instabilities. An analysis was also made on forward movements of the flame using a level-set method on video images. A StrouhalFroude relationship was found to roughly predict the maximum frequency of forward pulsations based on fire size and wind speed. More importantly, PDF functions of the flame were found to represent the intermittent movement of the flame, which resulted in further extensions at larger fire sizes and higher wind speeds. The flame length was also found to be related to the nondimensional fire size, however no correlations were found to adequately scale inclined flames. These results were scaled and included with larger scale studies in (Finney et al. 2015)

Further study of instabilities observed in flames was carried out by (Miller, Finney, et al. 2017; Miller, Tang, et al. 2017; Miller et al. 2018). In Miller, Tang, et al. (2017) a small-scale line burner was used in crossflow to track the growth and development of a laminar streak entering a flame. It was found that a shear instability most likely induced perturbations before the flame was present and lead to the appearance of stream wise streaks in the flame. However, the growth of these structures was eventually dominated by a Rayleigh-Taylor instability. In Miller et al. $(2017,2018)$ this work was extended using hot plates and a liquid wick to track the merging and growth of flow structures. It appeared that these initial streaks grow into larger-scale structures (peaks and troughs) which then dominate some forward flame motions. In (Finney et al. 2015), these structures were found to be important in fire spread because they break up the flame front and allow for forward bursts or pulsations of flame to move forward and provide convective heating and ignition for fine fuel particles.

Tang et al. (Tang, Gorham, et al. 2017; Tang, Miller, et al. 2017) performed two detailed studies on line fires under a wind field. First, the attachment length downstream of the burner and profiles of heat fluxes were presented. These quantities were correlated using a Richardson number, comparing the buoyancy produced from the flame vs. momentum from the oncoming wind, which described liftoff of the flame from the surface. Correlations were provided that collapsed heat fluxes to the 
downstream fuel surface both within the attached region and downstream liftoff or plume region. Tang, Miller, et al. 2017 later extended this work to investigate forward pulsations of the flame following the work of Gorham et al. (2014). Correlations for the maximum frequency location were found and the work from Gorham et al. (2014) extended to different fire sizes, however a full description of the forward movement of flames was not presented.

\section{Experimental Setup}

Forced-flow experiments were performed on a specially-designed $30 \mathrm{~cm}$ cross-section wind tunnel. This laminar blower was designed and built for uniform forced-flow combustion experiments. The wind velocity from the tunnel can be as high as $6 \mathrm{~m} / \mathrm{s}$, with turbulence intensities controlled below $2 \%$ for the velocities of interest (Singh and Gollner 2015). The experimental platform was placed immediately following the outlet of the exhaust tunnel. A sand-filled gas burner was used, with a 10 $\mathrm{cm}$ deep sand-filled plenum and a $25 \times 5 \mathrm{~cm}$ surface. The top surface of the burner was mounted flush with a sheet of ceramic fiber insulation board placed at the center of the blower outlet. The insulation board, with dimensions of 90 (length) $\times 45$ (width) $\times 10$ (height) $\mathrm{cm}^{3}$, provides a quasi-adiabatic surface for downstream fire contact during experiments. Propane from a gas cylinder was passed through a programmable flow meter to provide a steady flow rate of fuel during experiments. Three different fire heat release rates, $6.3,7.9,9.5 \mathrm{~kW}$, were used during the experiments. The wind velocity is varied from about 0.8 to $2.5 \mathrm{~m} / \mathrm{s}$. High-speed videography was used to capture digital images of the flame from the side view. The camera used was high-speed Nikon DX, recording at 250 frames per second at a pixel resolution of $1000 \times 720$. The experimental setup is shown in Fig. 1.

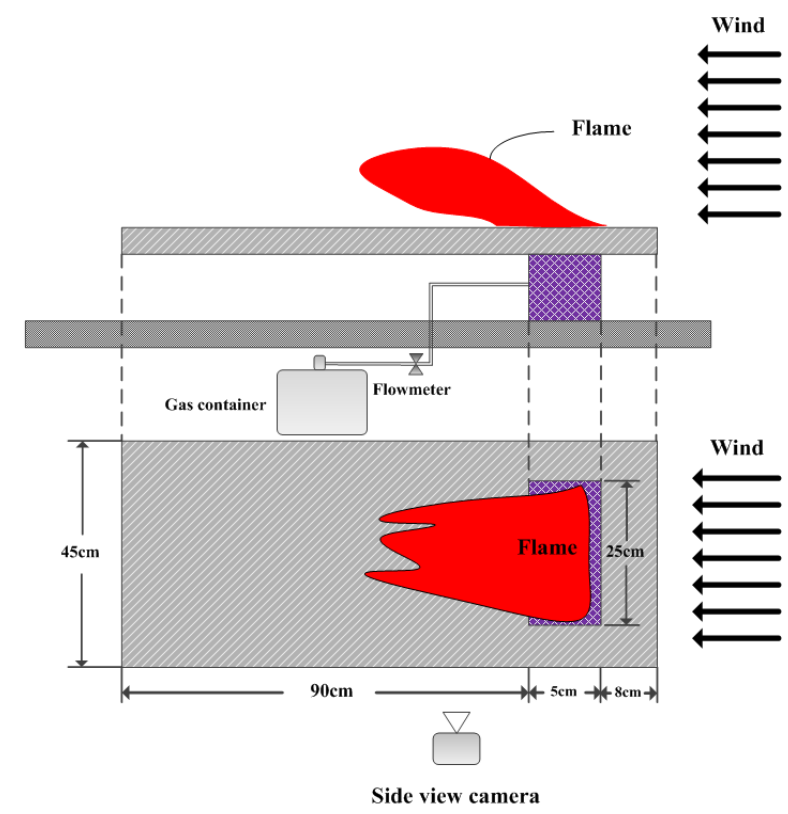

Figure 1 - Experimental setup used for forced-flow studies from (Tang, Gorham, et al. 2017).

\section{Results}

Experiments have been conducted over a variety of different wind-driven flame configurations and several inclined configurations, as reviewed above. In wind-driven studies, forward pulsation of the flame occurs as a result of the competition between the momentum provided by the ambient flow and upward buoyancy provided by the flame. A scaling analysis reveals that the forward pulsation frequency can be correlated with the Froude number (wind momentum over inertial force) and $Q^{*}$ (nondimensional buoyancy), 


$$
f=12.9\left(\frac{F r^{1 / 2}}{Q^{* 1 / 4}}\right)^{0.7}=12.9\left(\frac{F r}{Q^{* 1 / 2}}\right)^{0.35}
$$

Both the origin of structures observed on the fire line, e.g. streaks and peaks and troughs, and their role in influencing some of the macroscopic properties of the flow have also been examined. Streaks have been reproduced and characterized via experiments on stationary heated strips and liquid and gas-fueled burners in laminar boundary layer flows, providing a framework to develop theory based on both observed and measured physical phenomena. The incoming boundary layer is also established as the controlling mechanism in forming streaks, which are generated by pre-existing coherent structures, while the amplification of streaks was determined to be compatible with quadratic growth of Rayleigh-Taylor Instabilities, providing credence to the idea that the downstream growth of streaks is strongly tied to buoyancy. These local instabilities were also found to affect macroscopic properties of the flow, including heat transfer to the surface, indicating that a two-dimensional assumption may fail to adequately describe heat and mass transfer during flame spread and other reacting boundary layer flows.

Finally, new experiments on inclined surfaces with burners are been used to investigate flame attachment, where flames bend toward the surface accelerating heating and thus flame spread. The inclination also affects the formation of streaks and flame towers, suggesting these may play some role in the flame attachment process. This configuration continues to be studied, however preliminary results on attachment angle and heating will be presented.

\section{Acknowledgements}

This work was supported by the National Science Foundation (CBET-1554026) and a collaborative agreement with the USDA Forest Service (13-CS-11221637-124).

\section{References}

Ahmad T, Faeth GM (1979) Turbulent wall fires. Symposium (International) on Combustion 17, 1149 1160. doi:10.1016/S0082-0784(79)80109-5.

Alvares NJ, Blackshear PL, Kanury MA (1970) The Influence of Free Convection on the Ignition of Vertical Cellulosic Panels by Thermal Radiation. Combustion Science and Technology 1, 407-413. doi:10.1080/00102206908952220.

Baines PG (1990) Physical mechanisms for the propagation of surface fires. Mathematical and Computer Modelling 13, 83-94. doi:10.1016/0895-7177(90)90102-S.

Fang JB, Steward FR (1969) Flame spread through randomly packed fuel particles. Combustion and Flame 13, 392-398. doi:10.1016/0010-2180(69)90108-4.

Finney M a., Cohen JD, Forthofer JM, McAllister SS, Gollner MJ, Gorham DJ, Saito K, Akafuah NK, Adam B a., English JD (2015) Role of buoyant flame dynamics in wildfire spread. Proceedings of the National Academy of Sciences 112, 9833-9838. doi:10.1073/pnas.1504498112.

Gollner MJ, Miller CH, Tang W, Singh AV (2017) The effect of flow and geometry on concurrent flame spread. Fire Safety Journal. doi:10.1016/j.firesaf.2017.05.007.

Gorham DJ, Hakes R, Singh AV, Forthofer J, Cohen J, McAllister S, Finney MA, Gollner MJ (2014) Studying Wildfire Spread Using Stationary Burners. InXavier Viegas D (ed) 'VII Int. Conf. For. Fire Res.', Coimbra, Portugal.(Coimbra, Portugal)

Martin S (1965) Diffusion-controlled ignition of cellulosic materials by intense radiant energy. Symposium (International) on Combustion 10, 877-896. doi:10.1016/S0082-0784(65)80232-6. 
Miller C, Finney MA, McAllister S, Sluder E, Gollner MJ (2017) Investigating coherent streaks in wildfires via heated plates in crosswind. Fire Safety Journal 91,. doi:10.1016/j.firesaf.2017.03.035.

Miller CH, Tang W, Finney MA, McAllister SS, Forthofer JM, Gollner MJ (2017) An investigation of coherent structures in laminar boundary layer flames. Combustion and Flame 181, doi:10.1016/j.combustflame.2017.03.007.

Miller CH, Tang W, Sluder E, Finney MA, McAllister SS, Forthofer JM, Gollner MJ (2018) Boundary layer instabilities in mixed convection and diffusion flames with an unheated starting length. International Journal of Heat and Mass Transfer 118, doi:10.1016/j.ijheatmasstransfer.2017.11.040.

Quintiere JJG (1989) Scaling applications in fire research. Fire Safety Journal 15, 3-29. http://linkinghub.elsevier.com/retrieve/pii/0379711289900453.

Quintiere J, Harkleroad M, Hasemi Y (1986) Wall flames and implications for upward flame spread. Combustion Science and Technology 48, 191-222. http://www.bfrl.nist.gov/866/heatflux/pubs/Quintiere_Wall_Flames.pdf.

de Ris JL, Orloff L, Ris J De, Orloff L, de Ris JL, Orloff L (1975) The role of buoyancy direction and radiation in turbulent diffusion flames on surfaces. Symposium (International) on Combustion 15, 175-182. doi:10.1016/S0082-0784(75)80295-5.

Rothermel R (1972) A mathematical model for predicting fire spread in wildland fuels. (INT-115) doi:http://www.snap.uaf.edu/webshared/JenNorthway/AKFireModelingWorkshop/AKFireModeli ngWkshp/FSPro Analysis Guide References/Rothermel 1972 INT-115.pdf.

Rothermel R, Anderson H (1966) Fire spread characteristics determined in laboratory, US Forest Service Research Paper INT-30. http://www.fs.fed.us/rm/pubs_int/int_rp030.pdf.

Singh A V., Gollner MJ (2015) Estimation of local mass burning rates for steady laminar boundary layer diffusion flames. Proceedings of the Combustion Institute 35, 2527-2534. doi:10.1016/j.proci.2014.05.040.

Tang W, Gorham DJ, Finney MA, Mcallister S, Cohen J, Forthofer J, Gollner MJ (2017) An experimental study on the intermittent extension of flames in wind-driven fires. Fire Safety Journal 91,. doi:10.1016/j.firesaf.2017.03.030.

Tang W, Miller CH, Gollner MJ (2017) Local flame attachment and heat fluxes in wind-driven line fires. Proceedings of the Combustion Institute 36,. doi:10.1016/j.proci.2016.06.064. 